Journal of

\title{
Development of a Model Care Pathway for Adults undergoing Colorectal Cancer Surgery: evidence-based key interventions and indicators
}

\begin{tabular}{|c|c|}
\hline Journal: & Journal of Evaluation in Clinical Practice \\
\hline Manuscript ID & Draft \\
\hline Wiley - Manuscript type: & Systematic Review \\
\hline Date Submitted by the Author: & $\mathrm{n} / \mathrm{a}$ \\
\hline Complete List of Authors: & $\begin{array}{l}\text { Zelm, Ruben; Katholieke Universiteit Leuven, Leuven Institute for } \\
\text { Healthcare Policy; European Pathway Association; CQT Zorg \& Gezondheid, } \\
\text { Q-Consult } \\
\text { Janssen, Ingrid; European Pathway Association } \\
\text { Vanhaecht, Kris; Katholieke Universiteit Leuven, Leuven Institute for } \\
\text { Healthcare Policy; European Pathway Association } \\
\text { De Buck Van Overstraeten, Anthony; University Hospital Leuven, } \\
\text { Department of Abdominal surgery } \\
\text { Panella, Massimiliano; University of Eastern Piemonte (UPO), Department } \\
\text { of Translational Medicine; European Pathway Association } \\
\text { Sermeus, Walter; Katholieke Universiteit Leuven, Leuven Institute for } \\
\text { Healthcare Policy; European Pathway Association } \\
\text { Coeckelberghs, Ellen; Katholieke Universiteit Leuven, Leuven Institute for } \\
\text { Healthcare Policy }\end{array}$ \\
\hline Keywords: & structured reviews, clinical guidelines \\
\hline Abstract: & $\begin{array}{l}\text { Rationale, aims and objectives } \\
\text { During the last decades, perioperative care for patients with colorectal } \\
\text { cancer has shifted towards more standardized care, the so-called } \\
\text { 'enhanced recovery after surgery' (ERAS). Those programs aim to optimize } \\
\text { interventions in perioperative care in order to decrease the rate of } \\
\text { postoperative complications, improve patients' recovery, and shorten } \\
\text { hospital stay. The purpose of this literature review is to identify, } \\
\text { summarize and operationalize the clinical content of both key interventions } \\
\text { and clinical indicators in order to develop an evidence-based model } \\
\text { pathway for surgical patients with colorectal cancer. } \\
\text { Methods } \\
\text { A systematic search in three databases was conducted to identify key } \\
\text { interventions (KI) and indicators to measure the effect of implementation } \\
\text { of the care pathway.The KI's from the ERAS protocol were listed and used } \\
\text { as framework to identify and match the KI used in the included studies. } \\
\text { The Clinical Pathway Compass was used to categorize the indicators. } \\
\text { Results } \\
\text { Fifteen studies were included. The number of KI used in the study }\end{array}$ \\
\hline
\end{tabular}


protocols ranged from 9 - 20. In total, 33 KI's were identified. Little information was available concerning the implementation of and compliance to the protocol. Length of stay (LOS) and complication rate are the most common used indicators (used in 15/15 and 14/15 of the studies), followed by 21 other measures. All but 1 of the included studies reported a reduction in LOS.

Conclusion

There is considerable variation in both the number of key interventions and indicators as well as the operationalization of key interventions, for surgical patients with colorectal cancer documented in literature. Therefore, we summarized the input from the different studies and developed an evidence-based model pathway, which can serve as basis for a local / regional care pathway team to build their own pathway. 
Descriptive title: Development of a Model Care Pathway for Adults undergoing

Colorectal Cancer Surgery: evidence-based key interventions and indicators

\section{Running title: Model Care Pathway for Colorectal Cancer Surgery}

Ruben van Zelm ${ }^{1,2,3}$, MSc, Research fellow

Ingrid Janssen ${ }^{2}, \mathrm{MSc}$, Consultant

Kris Vanhaecht ${ }^{1,2}, \mathrm{PhD}$, Assistent professor

Anthony de Buck van Overstraeten ${ }^{4}, \mathrm{MD}$

Massimiliano Panella ${ }^{2,5}, \mathrm{PhD}$, Full Professor

Walter Sermeus ${ }^{1,2}$, PhD, Full Professor

Ellen Coeckelberghs ${ }^{1}, \mathrm{PhD}$, Post-Doc

\section{Affiliations}

1. Leuven Institute for Healthcare Policy, KU Leuven, Belgium

2. European Pathway Association, Leuven, Belgium

3. Q-Consult, Utrecht, the Netherlands

4. Department of abdominal surgery, University Hospital Leuven, KU Leuven, Belgium

5. Department of Translational Medicine, University of Eastern Piemonte (UPO), Novarra, Italy

\section{Corresponding author}

Ruben van Zelm

Research fellow, Leuven Institute for Healthcare Policy 
Department of Public Health and Primary Care

KU Leuven

Ruben.vanzelm@kuleuven.be

+31615862431

Key words

Care pathway, clinical pathway, colorectal surgery 


\title{
Descriptive title: Development of a Model Care Pathway for Adults undergoing colorectal cancer surgery: evidence-based key interventions and indicators
}

\section{Short title: Model Care Pathway for colorectal cancer surgery}

\begin{abstract}
Rationale, aims and objectives

During the last decades, perioperative care for patients with colorectal cancer has shifted towards more standardized care, the so-called 'enhanced recovery after surgery' (ERAS). Those programs aim to optimize interventions in perioperative care in order to decrease the rate of postoperative complications, improve patients' recovery, and shorten hospital stay. The purpose of this literature review is to identify, summarize and operationalize the clinical content of both key interventions and clinical indicators in order to develop an evidence-based model pathway for surgical patients with colorectal cancer.
\end{abstract}

\section{Methods}

A systematic search in three databases was conducted to identify key interventions $(\mathrm{KI})$ and indicators to measure the effect of implementation of the care pathway. The KI's from the ERAS protocol were listed and used as framework to identify and match the $\mathrm{KI}$ used in the included studies. The Clinical Pathway Compass was used to categorize the indicators.

Results

Fifteen studies were included. The number of $\mathrm{KI}$ used in the study protocols ranged 
from 9 - 20. In total, $33 \mathrm{Kl}$ 's were identified. Little information was available concerning the implementation of and compliance to the protocol. Length of stay (LOS) and complication rate are the most common used indicators (used in 15/15 and $14 / 15$ of the studies), followed by 21 other measures. All but 1 of the included studies reported a reduction in LOS.

\section{Conclusion}

There is considerable variation in both the number of key interventions and indicators as well as the operationalization of key interventions, for surgical patients with colorectal cancer documented in literature. Therefore, we summarized the input from the different studies and developed an evidence-based model pathway, which can serve as basis for a local / regional care pathway team to build their own pathway.

\section{Introduction}

During the last decades, perioperative care for patients with colorectal cancer has shifted towards more standardized care, the so-called 'enhanced recovery after surgery' (ERAS) documented in the ERAS-society protocol (1). These programs aim to optimize interventions in the perioperative care in order to decrease the rate of postoperative complications, improve patients' recovery, and shorten length of stay (LOS) (2,3). Recent guidelines strongly recommend the use of the ERAS program (4). The key interventions (or 'care elements' in ERAS terminology) of structured care methodologies like ERAS protocol in colorectal surgery, are based on the best evidence available. They include patient education and preparation, preservation of gut function, minimization of pain and discomfort and promotion of patient autonomy 
$(1,5)$. The most common interventions in pre- and postoperative care are nutritional management, pain management, and early mobilization $(5,6,7)$. Other interventions are fluid restriction, the use of thoracic epidurals, and preemptive analgesia $(6,7)$. The ERAS protocol is defined as 'a multimodal pathway'. This means that the protocol consists of multiple interventions working interactively to achieve early recovery for patients with major surgery, including colorectal cancer surgery. The interventions in the protocol are divided in three distinct phases of the care process: preoperative, intraoperative, and postoperative care $(1,6)$.

Despite growing evidence for the benefit of implementing such standardized programs, adherence remains difficult in daily practice $(2,5,8,10)$. One method to successfully implement and follow-up structured care methodologies in daily practice, is the development and implementation of a clinical pathway, also known as care pathway. A systematic review, published in Annals of Surgery 2014 defines care pathways as one of the proven interventions to reduce adverse events in surgery (11). A recent meta-analysis by Song et al. on the effects of clinical pathways for patients with gastro-intestinal cancer, shows a reduction in expenditure and higher patient satisfaction, and a significant reduction in average length of stay (12).

The European Pathway Association uses 'care pathway' as terminology. Their definition of a care pathway is: "a complex intervention for the mutual decision making and organization of care processes for a well-defined group of patients during a well-defined period". The aim of a care pathway is to enhance the quality of care across the continuum by improving risk-adjusted patient outcomes, promoting patient safety, increasing patient satisfaction and optimizing the use of resources (13).

A complex intervention is defined as a health service intervention, built up from a number of components, which may act both independently and interdependently 
(14). For the development and implementation of care pathways, these components are: 1) integration of a set of evidence based key interventions, 2) objective feedback on the current care process, and 3) systematic approach to change / improve current care process.

The purpose of this literature review is to identify, summarize and operationalize the clinical content of both key interventions and clinical indicators in order to develop an evidence-based model pathway for surgical patients with colorectal cancer (component 1 of the complex intervention). Therefore, evidence-based key interventions for a care pathway for surgical patients with colorectal cancer in pre-, intra-, and postoperative care (30 day follow-up) were listed and indicators measuring the effect of the care pathway were identified.

\section{Methods}

\section{Literature Search}

We conducted a systematic literature search in the three electronic databases (Medline, Embase and Cinahl) from 2006 (the end date of a previous systematic review on care pathways for patients with colorectal cancer surgery (5)) up to February 2014. The following terms were used: 'clinical pathway' combined with 'colorectal'; 'cancer', 'surgery', 'preoperative', 'perioperative', 'postoperative', 'fast track', 'enhanced recovery program'. All synonyms for these terms were included in the search. From this search, we included papers written in English, Dutch or German. In addition, the reference lists from published original and review articles were searched manually to identify other possible eligible studies.

\section{Study Selection}


Inclusion criteria were: 1) papers including adults undergoing elective colorectal surgery; 2) studies concerning the implementation and use of clinical/critical/care pathways in an inpatient setting; 3) retro- or prospective comparison with a control group (conventional/usual care); 4) studies reporting at least one of the following clinical relevant outcome measures: length of hospital stay, complication rates, readmission rates or mortality; and 5) published in a peer-reviewed journal between January 2006 and February 2014, as the model pathway was used in a study which started in October 2014. Studies not meeting all 5 criteria were excluded.

\section{Data extraction}

Two independent reviewers read all abstracts and made a selection of eligible studies. In case of disagreement, consensus was obtained on the articles that could be included for full-text analysis. All full-text articles were read by one reviewer to decide whether the article fulfilled the inclusion criteria. In case of any doubt the second reviewer was consulted and consensus was reached. A specifically developed data extraction sheet was used to gather data on study source, study design, level of evidence, sample size, pre-, intra- and postoperative interventions, and the studies' different outcome parameters and results. The content of the clinical pathway was divided into preoperative, intraoperative, and postoperative key interventions in accordance with the ERAS-protocol $(1,6)$. The ERAS protocol was used as framework for the data extraction of clinical content. We listed the 22 key interventions of the ERAS protocol and compared the key interventions used in the included studies with this list. Any additional interventions not listed in the ERAS protocol, where added to the list. 
For the clinical indicators, we used the Leuven Clinical Pathway Compass as framework (15). This compass consists of five domains in which indicators can be subdivided: clinical (e.g. complication rate, mortality), financial (e.g. LOS), process (e.g time between diagnosis and surgery), service (e.g. patient satisfaction), and team indicators (e.g. job satisfaction, team effectivity). The compass serves as a conceptual framework specifically developed to measure the effect of care pathways and to follow-up a patient population (15).

\section{Statistical Analysis}

Descriptive statistics were used to summarize our results. Categorical data were presented by their observed frequencies and percentages.

\section{Results}

\section{Literature Search}

One hundred eighty potentially relevant studies were retrieved from the search in the electronic databases, and 2 extra studies were found by manual search and cross referencing. Sixty one papers met all the mentioned inclusion criteria, of which, 3 were unavailable/irretrievable, 10 compared open vs laparoscopic technique, regardless of fast track and 7 were non-comparative studies. Papers commenting on other studies, sharing the same population or protocol/pathway, reporting the effect of one single intervention (e.g. early mobilization) were also excluded. Ultimately, 15 studies were included in the analysis (Figure 1).

$<$ figure 1>> 
The study methodologies were very heterogeneous: 4 papers were prospective comparative studies $(16,17,18,19), 5$ were RCT's $(20,21,22,23,24), 3$ were preposttest designs $(3,25,26)$, and 3 were observational studies $(8,9,27)$. Three were multicenter studies $(8,17,25)$.

We rated the studies according to the levels of evidence from the Oxford Centre of Evidence Based Medicine (28). See Annex 1 for the study characteristics.

\section{Key interventions}

Many studies named the interventions or protocols differently. The most common names were ERAS (Enhanced Recovery After Surgery), ERP (Enhanced Recovery Protocol) or 'Fast Track'. Moreover, the content of the protocols differed. The number of key interventions (or care elements) that are listed in the included studies range from 9 interventions (25) to 20 interventions (27). In comparison, the ERAS protocol contains 22 care elements. The reported interventions and their usage are summarized in Table 1. The description or operationalisation of the specific interventions differs between the studies. For example the key intervention "No prolonged fasting" is described as "Fluids up till 3h before surgery" (21), but also as "Clear fluids until $2 \mathrm{~h}$ before initiation of anesthesia and $6 \mathrm{~h}$ for solid food" (24). A more detailed overview of the different descriptions of the key interventions is provided in Annex 2.

We identified a number of interventions used in the included studies that are not included in the ERAS protocol. In total, 33 key interventions were listed, of which 11 were not included in the ERAS protocol. 
$<<$ table $1>>$

\section{Clinical indicators}

The indicators that were used in the included studies were identified and allocated to the domains of the Clinical Pathway Compass. Clinical and financial indicators are used in all 15 studies. Two of the studies used process indicators, two studies used a service indicator. Indicators in the team-domain were not used.

The most common used (outcome) indicators are LOS (15/15) and complication rate (14/15). Table 2 presents the individual indicators used to measure the effect of using ERAS/fast track, and the observed effect. All but 1 study report reduction in LOS. Other outcome indicators, e.g. complication rate, mortality, readmission rate, show no effect. In none of the studies a negative effect is reported. This implies that LOS can be reduced without compromising the quality of care.

$<$ table $2>>$

\section{Discussion}

Since the publication of the report "To Err is Human" in 2000 (Institute of Medicine IOM), attention to quality of care is increasing (29). In order to provide high quality care, overuse and particularly underuse of evidence based activities should be eliminated $(30,31)$. Care pathways, also known as critical pathways or clinical pathways, are used worldwide as one of the tools to structure or design care processes around patients' needs and, by doing so, to improve the quality of 
delivered care (32). However, to the best of our knowledge, there is no evidencebased model (clinical) pathway available yet.

ERAS or fast track pathways are strongly suggested in current clinical guidelines (4). Nevertheless, most of the included studies incorporated only a limited number of key interventions from the original ERAS protocol. Even routine interventions, such as thromboprophylaxis and antibiotic prophylaxis, are only mentioned in 1 study protocol (27). ERAS is a multimodal pathway, suggesting that the different elements are applied together. Alcantara-Moral et al. found that the more interventions from the protocol are applied, the shorter the LOS, with similar morbidity and without any increase in readmissions or reinterventions (8). We believe that in this matter 'more is better'. An enhanced recovery protocol is a complex intervention, built up from a number of components, which may act both independently and interdependently (14). Not applying the suggested, evidence-based key interventions could mean that patients do not receive optimal care, and in fact are undertreated.

We advise caution in interpreting the effect of the key interventions. First of all, although we present an overview of the key interventions used in these pathways, we did not consider the evidence for the rationale behind each specific key intervention. Most of the ERAS care elements are used in studies that provide moderate evidence (level II + level III studies). Exceptions are Antibiotic prophylaxis and Thromboprophylaxis, and Maintenance of normothermia, which are used in lower level studies. From the 11 additional key interventions we identified, Type of incision and Laparoscopic access are also used in studies that provide moderate evidence. The other 9 interventions are used in studies that support weak evidence. However, 
this does not mean that routine interventions, such as administering antibiotic prophylaxis, or weighing the patient, are to be excluded from the care pathway. There might be other evidence, based on guidelines and studies for these interventions (e.g. guidelines on antibiotic prophylaxis), or clinical expertise (e.g. monitoring body weight as important indicator) supporting the application of the interventions. We listed the interventions in our overview, including references and description, so that teams can consider the appropriateness of including this intervention in their local care pathway.

Secondly, the level of compliance to the protocols is unknown. Polle et al. evaluated compliance to the ERAS interventions and found that patients received on average 7.4 out of 13 key interventions (3). Alcantara-Moral et al. report a slightly higher compliance: 8.4 out of 13 interventions (8). This means it is difficult or even impossible to determine the level of implementation fidelity and spread, for both the complete protocols, and the individual key interventions. It is therefore impossible to conclude which intervention is contributing to what effect.

The indicators used in the included studies, suggest that there is primarily attention to clinical and financial outcomes. LOS is predominantly used, followed by complication rate. The other domains receive little (process and service) or no (team) attention. This is in line with a previous review by Lemmens et al. (33). The process domain should deserve more attention, especially 'compliance to protocol'. The service domain, with indicators e.g. patient satisfaction, patient experience, is an important domain to include in studies concerning a patient centered concept such as care pathways. The team domain is completely overlooked. We think this is an omission, because it is people that make care pathways work. Deneckere et al. showed that 
teams working with care pathways have better team performance (teamwork, higher level of organized care, and lower burnout risk) than teams not working with pathways (34).

The indicators that are used in the included studies, show a wide variety in topics. It could be useful to develop an international set of common indicators, so that teams can compare their results internationally.

\section{Strength and limitations}

This review comes with its strengths and limitations. We made a strict selection of eligible studies, only peer-reviewed, comparative studies on care pathways were retained, which strengthens this review. On the other hand, there are two limitations. First of all, we only found positive results, which raises questions about publication bias. Second, the included studies use different methodologies, and some of the studies with a stronger design have a small population.

\section{Conclusion}

We have observed considerable variation in both the number of key interventions and indicators as well as the operationalization of the key interventions, for surgical patients with colorectal cancer documented in the literature. Therefore, we summarized the input from the different studies and developed an evidence-based model pathway, which can serve as a basis for a local / regional care pathway team to build their own pathway.

Next to the model pathway we present input for current and future indicator selection for monitoring and follow-up of surgical patients with colorectal cancer. 
Compliance to care pathways or protocols can be difficult, but has to be strived for, in order to deliver the best possible care for patients. Different type of indicators, e.g. clinical (complication rate, time to first bowel movement, mobilization), financial (LOS), and process (compliance) should be monitored to gain insight in performance of the team.

$<$ Annex 1\&2 >> 


\section{Conflict of interest}

Research made possible by an unconditional educational grant by Baxter SA. Baxter SA had no influence on the review.

\section{Contributions}

I.J. performed the literature search, I.J. and R.v.Z. selected the studies. R.v.Z. and E.C. summarized the studies and prepared the draft. K.V. and A.d.B.v.O. supervised the review and commented on the draft. M.P. and W.S. commented on the final draft. 


\section{References}

1. ERAS-society. ERAS protocol (EP) 2016

http://www.erassociety.org/index.php/eras-care-system/eras-protocol. Accessed February 2, 2016.

2. Aarts M, Okrainec A, Glicksman A, Pearsall A, Victor J, McLeod R. Adoption of enhanced recovery after surgery (ERAS) strategies for colorectal surgery at academic teaching hospitals and impact on total length of hospital stay. Surgical Endoscopy. 2012;26:442-450.

3. Polle S, Wind J, Fuhring J, Hofland J, Gouma D, Bemelman W. Implementation of a fast-track perioperative care program: What are the difficulties? Digestive Surgery. 2007;24:441-449.

4. Peeters M, Leroy R, Robays J, et al. Colon Cancer: Diagnosis, Treatment and Follow-Up. Good Clinical Practice (GCP). Brussels: Belgian Health Care Knowledge Centre (KCE). KCE Reports 218. D/2014/10.273/15, 2014.

5. Lemmens L, Van Zelm R, Borel Rinkes I, Van Hillegersberg R, Kerkkamp H. Clinical and Organizational Content of Clinical Pathways for Digestive Surgery: A Systematic Review. Digestive Surgery. 2009;26:91-99

6. Gustafsson UO, Scott MJ, Schwenk W, et al. Guidelines for Perioperative Care in Elective Colonic Surgery: Enhanced Recovery After Surgery (ERAS) Society Recommendations. World Journal of Surgery. 2013;37:259-284.

7. Nygren J, Thacker J, Carli F. et al. Guidelines for Perioperative Care in Elective Rectal/Pelvic Surgery: Enhanced Recovery After Surgery (ERAS) Society Recommendations. World Journal of Surgery. 2013;37:285-305.

8. Alcantara-Moral M, Serra-Aracil X, Gil-Egea MJ, Frasson M, Flor-Lorente B, Garcia-Granero E. Observational cross-sectional study of compliance with the fast 
track protocol in elective surgery for colon cancer in Spain. International Journal of Colorectal Disease. 2014;29(4):477-483.

9. Christensen HK, Thaysen HV, Rodt SA, Carlsson P, Laurberg S. Short Hospital Stay and Low Complication Rate Are Possible with a Fully Implemented FastTrack Model after Elective Colonic Surgery. European Surgical Research. 2011;46:156-161.

10. Ramirez JM, Blasco JA, Roig JV, et al. Enhanced recovery in colorectal surgery: a multicentre study. BMC surgery. 2011;11(9):1471-2482.

11. Howell AM, Panesar SS, Burns EM, Donaldson LJ, Darzi A. Reducing the burden of surgical harm: a systematic review of the interventions used to reduce adverse events in surgery. Annals of Surgery. 2014;259(4):630-641.

12.Song XP, Tian JH, Cui Q, Zhang TT, Yang KH, Ding GW. Could clinical pathways improve the quality of care in patients with gastrointestinal cancer? A metaanalysis. Asian Pacific Journal of Cancer Prevention 2014;15(19):8361-8366.

13. Vanhaecht K, De Witte K, Sermeus W. (2007). The impact of clinical pathways on the organisation of care processes. Leuven: ACCO; 2007.

14. Medical Research Council (MRC). A framework for development and evaluation of RCTs for complex interventions to improve health. London: MRC; 2000.

15. Vanhaecht K, Sermeus W. The Leuven Clinical Pathway Compass. Journal of Integrated Care Pathways. 2003;7:2-7.

16. Feo CV, Lanzara S, Sortini D. et al. Fast track postoperative management after elective colorectal surgery: a controlled trail. American Surgeon. $2009 ; 75(12): 1247-1251$.

17. Gouvas N, Gogos-Pappas G, Tsimogiannis K, Tsimoyiannis E, Dervenis C, Xynos E. Implementation of fast-track protocols in open and laparoscopic sphincter- 
preserving rectal cancer surgery: a multicenter, comparative, prospective, nonrandomized study. Digestive Surgery. 2012;29(4):301-309.

18. King PM, Blazeby JM, Ewings $P$, et al. Randomized clinical trial comparing laparoscopic and open surgery for colorectal cancer within an enhanced recovery programme. British Journal of Surgery. 2006;93(3):300-308.

19. Moronczyk DA, Krasnodebski IW. Implementation of the fast track surgery in patients undergoing the colonic resection: own experience. Polski Przeglad Chirurgiczny. 2011;83(9):482-487.

20. lonescu D, lancu C, Ion D, et al. Implementing fast-track protocol for colorectal surgery: a prospective randomized clinical trial. World Journal of Surgery. 2009;33(11):2433-2438.

21. Khoo CK, Vickery CJ, Forsyth N, Vinall NS, Eyre-Brook IA. A prospective randomized controlled trial of multimodal perioperative management protocol in patients undergoing elective colorectal resection for cancer. Annals of Surgery. 2007;245(6):867-872.

22. Ren L, Zhu D, Wei Y, et al. Enhanced Recovery After Surgery (ERAS) program attenuates stress and accelerates recovery in patients after radical resection for colorectal cancer: a prospective randomized controlled trial. World Journal of Surgery, 2012;36(2):407-414.

23. Wang G, Jiang ZW, Xu J, et al. Fast-track rehabilitation program vs conventional care after colorectal resection: a randomized clinical trial. World Journal of Gastroenterology. 2011;17(5):671-676.

24. Wang G, Jiang ZW, Zhao K, et al. Fast track rehabilitation programme enhances functional recovery after laparoscopic colonic resection. HepatoGastroenterology. 2012;59(119):2158-2163. 
25. Lloyd GM, Kirby R, Hemingway DM, Keane FB, Miller AS, Neary P. The RAPID protocol enhances patient recovery after both laparoscopic and open colorectal resections. Surgical Endoscopy. 2010;24(6):1434-1439.

26. Schwarzbach M, Hasenberg T, Linke M, Kienle P, Post S, Ronellenfitsch U. Perioperative quality of care is modulated by process management with clinical pathways for fast-track surgery of the colon. International Journal of Colorectal Disease. 2011;26:1567-1575.

27. Huibers CJA, De Roos MAJ, Ong KH. The effect of the introduction of the ERAS protocol in laparoscopic total mesorectal excision for rectal cancer. International Journal of Colorectal Disease. 2012;27(6):751-757.

28. Oxford Centre for Evidence-Based Medicine (OCEBM) Levels of Evidence Working Group. (2016). The Oxford 2011 Levels of Evidence.

http://www.cebm.net. Accessed February 2, 2016.

29. Kohn LT, Corrigan JM, Donaldson MS. (Eds.). To Err Is Human. Building a safer Health System. Committee on Quality of Health Care in America, Institute of Medicine. Washington, D.C.: National Academy Press; 2000.

30. Committee on Quality of Health Care in America. Crossing the Quality Chasm. A New Health System for the 21st Century. Institute of Medicine. Washington, D.C.: National Academy Press; 2001.

31. McGlynn EA, Asch SM, Adams J, et al. The Quality of Health Care Delivered to Adults in the United States. New England Journal of Medicine. 2003;348:26352654.

32. Vanhaecht K, Panella M, Van Zelm R, Sermeus W. An overview on the history and concept of care pathways as complex interventions. International Journal of Care Pathways. 2010;14:117-123. 
33. Lemmens L, Van Zelm R, Vanhaecht K, Kerkkamp H. Systematic review: indicators to evaluate effectiveness of clinical pathways for gastrointestinal surgery. Journal of Evaluation in Clinical Practice. 2008;14:880-887.

34. Deneckere S, Euwema M, Lodewijckx C, et al. Better Interprofessional Teamwork, Higher Level of Organized Care, and Lower Risk of Burnout in Acute Health Care Teams Using Care Pathways. A Cluster Randomized Controlled Trial. Medical Care, 2013;51:99-107. 


\section{Figure Legends}

Figure 1. Systematic review flow diagram

Table 1. Key interventions for patients undergoing colorectal cancer surgery Legend: Gen=General;Pre=Preoperative;Intra=Intraoperative;Post=Postoperative

Table 2. Indicators per domain of Clinical Pathway Compass, and effect per indicator

Legend: Indicators used to evaluate the effect of clinical pathway/ERAS protocol. Number of studies=number of included papers that describe the specific indicator. Positive effect, No effect, Negative effect=proportion of papers that describe the specific indicator, that show improvement, no difference, or deterioration in outcome. References by first author between brackets.

LOS=Length Of Stay;HDU=High Dependency Unit;ICU=Intensive Care Unit *study reported improvement for laparoscopic group, and no difference for open group

\section{Annex 1. Characteristics of included studies}

Legend: $\mathrm{D}=$ days; $\mathrm{KI}=$ number of key interventions used in study;ns=not significant

\section{Annex 2. Components Care Pathway for surgical patients with colorectal} cancer

Legend: Day $0=$ day of surgery, day $1=1$ st postoperative day, et cetera. Blue $=$ add on to ERAS protocol 
Table 1. Key interventions for patients undergoing colorectal cancer surgery

\begin{tabular}{|c|c|c|c|c|}
\hline Phase & Intervention & $\begin{array}{l}\text { Eras } \\
\text { element }\end{array}$ & Used & Reference by first author \\
\hline Gen & Dedicated ward & $\mathrm{N}$ & $2 / 15$ & Christensen; Khoo \\
\hline Gen & Dedicated team & $\mathrm{N}$ & $2 / 15$ & Christensen; Feo \\
\hline Gen & $\begin{array}{l}\text { OR scheduling (Tu or Wed, } 1^{\text {st }} \text { on } \\
\text { program) }\end{array}$ & $\mathrm{N}$ & $1 / 15$ & Christensen \\
\hline Pre & Fluid and carbohydrate loading & Y & $10 / 15$ & $\begin{array}{l}\text { Alcantara-Moral; Gouvas; } \\
\text { Huibers; Ionescu; Khoo; King } \\
\text { Polle; Ren; Wang (2012); Wang } \\
\text { (2011) }\end{array}$ \\
\hline Pre & No/selective bowel preparation & Y & 9/15 & $\begin{array}{l}\text { Alcantara-Moral; Christensen; } \\
\text { Huibers; Ionescu; Moronczyk; } \\
\text { Ren; Schwarzbach; Wang (2012); } \\
\text { Wang (2011) }\end{array}$ \\
\hline Pre & Preadmissions counseling & Y & $8 / 15$ & $\begin{array}{l}\text { Christensen; Gouvas; Huibers; } \\
\text { Ionescu; King } \\
\text { Moronczyk; Polle; Wang (2011) }\end{array}$ \\
\hline Pre & No prolonged fasting & Y & $6 / 15$ & $\begin{array}{l}\text { Gouvas; Huibers; Khoo; Polle; } \\
\text { Wang (2012); Wang (2011) }\end{array}$ \\
\hline Pre & No premedication & Y & $4 / 15$ & $\begin{array}{l}\text { Alcantara-Moral; Christensen; } \\
\text { Polle; Wang (2011) }\end{array}$ \\
\hline Pre & Antibiotic profylaxis & Y & $1 / 15$ & Huibers \\
\hline Pre & Thromboprofylaxis & Y & $1 / 15$ & Huibers \\
\hline Intra & $\begin{array}{l}\text { Mid-thoracic epidural } \\
\text { anesthesia/analgesia }\end{array}$ & Y & $12 / 15$ & $\begin{array}{l}\text { Alcantara-Moral; Christensen; } \\
\text { Gouvas; Huibers; Ionescu; Khoo; } \\
\text { King; Polle; Ren; Schwarzbach; } \\
\text { Wang (2012); Wang (2011) }\end{array}$ \\
\hline Intra & Avoidance of salt and water overload & Y & $8 / 15$ & $\begin{array}{l}\text { Alcantara-Moral; Christensen; } \\
\text { Gouvas; Khoo; King; Polle; } \\
\text { Schwarzbach; Wang (2011) }\end{array}$ \\
\hline Intra & Short acting anesthetic agents & Y & $7 / 15$ & $\begin{array}{l}\text { Christensen; Feo; Khoo; King; } \\
\text { Polle; Wang (2012); Wang (2011) }\end{array}$ \\
\hline Intra & No drains & Y & $7 / 15$ & $\begin{array}{l}\text { Alcantara-Moral; Khoo; } \\
\text { Moronczyk; Polle; Ren; Wang } \\
\text { (2012); Wang (2011) }\end{array}$ \\
\hline Intra & Laparoscopic technique & $\mathrm{N}$ & $5 / 15$ & $\begin{array}{l}\text { Gouvas; Huibers; Lloyd; Polle; } \\
\text { Wang (2012) }\end{array}$ \\
\hline Intra & $\begin{array}{l}\text { Maintenance of normothermia } \\
\text { (bodywarmer/warm IV fluids) }\end{array}$ & Y & $4 / 15$ & $\begin{array}{l}\text { Alcantara-Moral; Gouvas; } \\
\text { Huibers; Polle }\end{array}$ \\
\hline Intra & Incision & $\mathrm{N}$ & $4 / 15$ & $\begin{array}{l}\text { Christensen; King; Polle; Wang } \\
(2011)\end{array}$ \\
\hline Intra & Wound infiltration & $\mathrm{N}$ & $3 / 15$ & Moronczyk; Polle; Wang (2011) \\
\hline Intra & Preemptive analgesia & $\mathrm{N}$ & $2 / 15$ & Christensen; Huibers \\
\hline Intra & Standard ASA monitors & $\mathrm{N}$ & $1 / 15$ & Feo \\
\hline Post & Early mobilization & Y & $15 / 15$ & $\begin{array}{l}\text { Alcantara-Moral; Christensen; } \\
\text { Feo; Gouvas; Huibers; Ionescu; } \\
\text { Khoo; King; } \\
\text { Lloyd; Moronczyk; Polle; Ren; } \\
\text { Schwarzbach; Wang (2012); } \\
\text { Wang (2011) }\end{array}$ \\
\hline
\end{tabular}




\begin{tabular}{|c|c|c|c|c|}
\hline Post & Early oral nutrition & Y & $14 / 15$ & $\begin{array}{l}\text { Alcantara-Moral; Christensen; } \\
\text { Feo; Gouvas; Huibers; Ionescu; } \\
\text { Khoo; King; } \\
\text { Lloyd; Moronczyk; Polle; Ren; } \\
\text { Schwarzbach; Wang (2011) }\end{array}$ \\
\hline Post & $\begin{array}{l}\text { Mid-thoracic epidural } \\
\text { anesthesia/analgesia }\end{array}$ & Y & $13 / 15$ & $\begin{array}{l}\text { Alcantara-Moral; Christensen; } \\
\text { Feo; Gouvas; Huibers; Ionescu; } \\
\text { Khoo; King } \\
\text { Moronczyk; Polle; Schwarzbach; } \\
\text { Wang (2012); Wang (2011) }\end{array}$ \\
\hline Post & No nasogastric tubes & Y & $13 / 15$ & $\begin{array}{l}\text { Alcantara-Moral; Feo; Gouvas; } \\
\text { Huibers; Ionescu; Khoo; King; } \\
\text { Lloyd; Moronczyk; Polle; Ren; } \\
\text { Schwarzbach; Wang (2011) }\end{array}$ \\
\hline Post & Non-opioid oral analgesia/NSAIDs & Y & $13 / 15$ & $\begin{array}{l}\text { Alcantara-Moral; Christensen; } \\
\text { Gouvas; Huibers; Ionescu; Khoo; } \\
\text { King; } \\
\text { Lloyd; Moronczyk; Polle; Ren; } \\
\text { Schwarzbach; }\end{array}$ \\
\hline Post & Audit of compliance and outcomes & Y & $12 / 15$ & $\begin{array}{l}\text { Feo; Gouvas; Huibers; Ionescu; } \\
\text { King Lloyd; Moronczyk; Polle; } \\
\text { Ren; Schwarzbach; Wang (2012); } \\
\text { Wang (2011) }\end{array}$ \\
\hline Post & Early removal of cathether & $\mathrm{Y}$ & $11 / 15$ & $\begin{array}{l}\text { Christensen; Gouvas; Huibers; } \\
\text { Ionescu; Khoo; King; Lloyd; } \\
\text { Moronczyk; Schwarzbach; Wang } \\
\text { (2012); Wang (2011) }\end{array}$ \\
\hline Post & Prevention of nausea and vomiting & $\mathrm{Y}$ & $10 / 15$ & $\begin{array}{l}\text { Alcantara-Moral; Christensen; } \\
\text { Huibers; Ionescu; Khoo; Lloyd; } \\
\text { Polle; Ren; Wang (2012); Wang } \\
\text { (2011) }\end{array}$ \\
\hline Post & Avoidance of salt and water overload & Y & $9 / 15$ & $\begin{array}{l}\text { Christensen; Huibers; Khoo; } \\
\text { Lloyd; Moronczyk; Polle; Ren; } \\
\text { Schwarzbach; Wang (2011) }\end{array}$ \\
\hline Post & Stimulation of gut motility & Y & $6 / 15$ & $\begin{array}{l}\text { Alcantara-Moral; Christensen; } \\
\text { Huibers; Khoo; Ren; Schwarzbach }\end{array}$ \\
\hline Post & Respiratory training & $\mathrm{N}$ & $1 / 15$ & Schwarzbach \\
\hline Post & $\begin{array}{l}\text { Routine monitoring at Medium Care } \\
\text { Unit }\end{array}$ & $\mathrm{N}$ & $1 / 15$ & Schwarzbach \\
\hline Post & Body weight & $\mathrm{N}$ & $1 / 15$ & Christensen \\
\hline
\end{tabular}

Gen=General;Pre=Preoperative;Intra=Intraoperative;Post=Postoperative 
Table 2. Indicators per domain of Clinical Pathway Compass, and effect per indicator Indicators used to evaluate the effect of clinical pathway/ERAS protocol.

Number of studies = number of included papers that describe the specific indicator.

Positive effect, No effect, Negative effect=proportion of papers that describe the specific indicator, that show improvement, no difference, or deterioration in outcome.

References by first author between brackets.

\begin{tabular}{|c|c|c|c|c|}
\hline Clinical domain & $\begin{array}{l}\text { \# of } \\
\text { studies }\end{array}$ & Positive effect & No effect & Negative effect \\
\hline Complication rate & $14 / 15$ & 7\% (Gouvas) & $\begin{array}{l}\text { 93\% (Alcantara-Moral; } \\
\text { Christensen; Feo; Huibers; } \\
\text { Ionescu; Khoo; King; } \\
\text { Lloyd; Moronczyk; Polle; } \\
\text { Ren; Schwarzbach; Wang } \\
\text { (2012); Wang (2011)) }\end{array}$ & \\
\hline $\begin{array}{l}\text { Readmission rate } \\
(<30 d)\end{array}$ & $11 / 15$ & & $\begin{array}{l}\mathbf{1 0 0 \%} \text { (Alcantara-Moral; } \\
\text { Christensen; Gouvas; } \\
\text { Huibers; Ionescu; King; } \\
\text { Lloyd; Moronczyk; Polle; } \\
\text { Schwarzbach; Wang } \\
(2011))\end{array}$ & \\
\hline $\begin{array}{l}\text { Time to passage } \\
\text { of stool }\end{array}$ & $9 / 15$ & $\begin{array}{l}\text { 56\% (Gouvas; Huibers; } \\
\text { Ionescu; Khoo; Ren) }\end{array}$ & $\begin{array}{l}\text { 44\% (Feo; Lloyd; } \\
\text { Moronczyk; Schwarzbach) }\end{array}$ & \\
\hline Time to solid diet & $7 / 15$ & $\begin{array}{l}\mathbf{8 6 \%} \text { (Ionescu; } \\
\text { Moronczyk; } \\
\text { Schwarzbach; Wang } \\
(2012))\end{array}$ & 14\% (Lloyd) & \\
\hline Mortality & $6 / 15$ & & $\begin{array}{l}\text { 100\% (Gouvas; Huibers; } \\
\text { King; Moronczyk; Polle; } \\
\text { Schwarzbach) }\end{array}$ & \\
\hline $\begin{array}{l}\text { Reoperations / } \\
\text { reinterventions }\end{array}$ & $6 / 15$ & 17\% (Moronczyk) & $\begin{array}{l}\mathbf{8 3 \%} \text { (Alcantara-Moral; } \\
\text { Huibers; King; Polle; } \\
\text { Schwarzbach) }\end{array}$ & \\
\hline $\begin{array}{l}\text { Time to passage } \\
\text { of flatus }\end{array}$ & $4 / 15$ & $\begin{array}{l}\text { 75\% (Ren; Wang (2012); } \\
\text { Wang (2011)) }\end{array}$ & $25 \%(\mathrm{Feo})$ & \\
\hline $\begin{array}{l}\text { Time to } \\
\text { independent } \\
\text { mobility }\end{array}$ & $5 / 15$ & $\begin{array}{l}\text { 100\% (Ionescu; Khoo; } \\
\text { Schwarzbach; Wang } \\
\text { (2012) Wang 2011)) }\end{array}$ & & \\
\hline $\begin{array}{l}\text { Postoperative } \\
\text { pain }\end{array}$ & $3 / 15$ & $\begin{array}{l}\text { 100\% (Gouvas; Ionescu; } \\
\text { Lloyd }^{*} \text { ) }\end{array}$ & $33 \%\left(\right.$ Lloyd $\left.^{*}\right)$ & \\
\hline Vomiting & $3 / 15$ & & $\begin{array}{l}\mathbf{1 0 0 \%} \text { (Feo; Ionescu; } \\
\text { Moronczyk) }\end{array}$ & 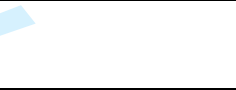 \\
\hline $\begin{array}{l}\text { Time to remove } \\
\text { catheter }\end{array}$ & $3 / 15$ & $\begin{array}{l}\text { 67\% (Moronczyk; Wang } \\
(2012))\end{array}$ & 33\% (Schwarzbach) & \\
\hline $\begin{array}{l}\text { Time to semi- } \\
\text { liquid diet }\end{array}$ & $2 / 15$ & $\begin{array}{l}\mathbf{1 0 0 \%} \text { (Ionescu; Wang } \\
(2012))\end{array}$ & & \\
\hline $\begin{array}{l}\text { Time to remove } \\
\text { drain }\end{array}$ & $1 / 15$ & 100\% (Moronczyk) & & \\
\hline Use of NG tubes & $1 / 15$ & & $100 \%($ Feo $)$ & \\
\hline $\begin{array}{l}\text { Use of Central } \\
\text { Venous Catheter }\end{array}$ & $1 / 15$ & & 100\% (Schwarzbach) & \\
\hline Use of epidural & $1 / 15$ & 100\% (Schwarzbach) & & \\
\hline
\end{tabular}




\begin{tabular}{|c|c|c|c|c|}
\hline catheter & & & & \\
\hline Use of drains & $1 / 15$ & 100\% (Wang (2012)) & & \\
\hline $\begin{array}{l}\text { Nutrition and } \\
\text { metabolism index }\end{array}$ & $1 / 15$ & $100 \%$ (Ren) & & \\
\hline Stress index & $1 / 15$ & $100 \%$ (Ren) & & \\
\hline \multicolumn{5}{|l|}{ Fincanial domain } \\
\hline $\begin{array}{l}\text { (Postoperative) } \\
\text { length of stay }\end{array}$ & $15 / 15$ & $\begin{array}{l}\text { 93\% Alcantara-Moral; } \\
\text { Christensen; Feo; } \\
\text { Gouvas; Huibers; } \\
\text { Ionescu; Khoo; King; } \\
\text { Lloyd; Moronczyk; Polle; } \\
\text { Ren; Wang (2012); Wang } \\
\text { (2011) }\end{array}$ & 7\% (Schwarzbach) & \\
\hline Cost & $2 / 15$ & 100\% (King; Ren) & & \\
\hline LOS in HDU/ICU & $1 / 15$ & $100 \%$ (Ionescu) & & \\
\hline \multicolumn{5}{|l|}{ Process domain } \\
\hline $\begin{array}{l}\text { Compliance to } \\
\text { protocol }\end{array}$ & $2 / 15$ & $\begin{array}{l}\text { 100\% (Alcatara-Moral; } \\
\text { Polle) }\end{array}$ & & \\
\hline Service domain & & & & \\
\hline Quality of life & $1 / 15$ & 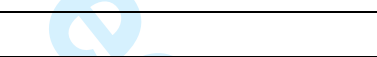 & $100 \%$ (King) & \\
\hline $\begin{array}{l}\text { Patient } \\
\text { satisfaction }\end{array}$ & $1 / 15$ & & $100 \%$ (Polle) & \\
\hline Team domain & & 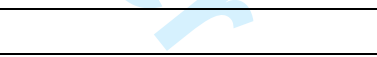 & & \\
\hline- & - & $x^{2+20}$ & & \\
\hline
\end{tabular}

LOS=Length Of Stay;HDU=High Dependency Unit;ICU=Intensive Care Unit

*study reported improvement for laparoscopic group, and no difference for open group 
Figure 1. Systematic review flow diagram

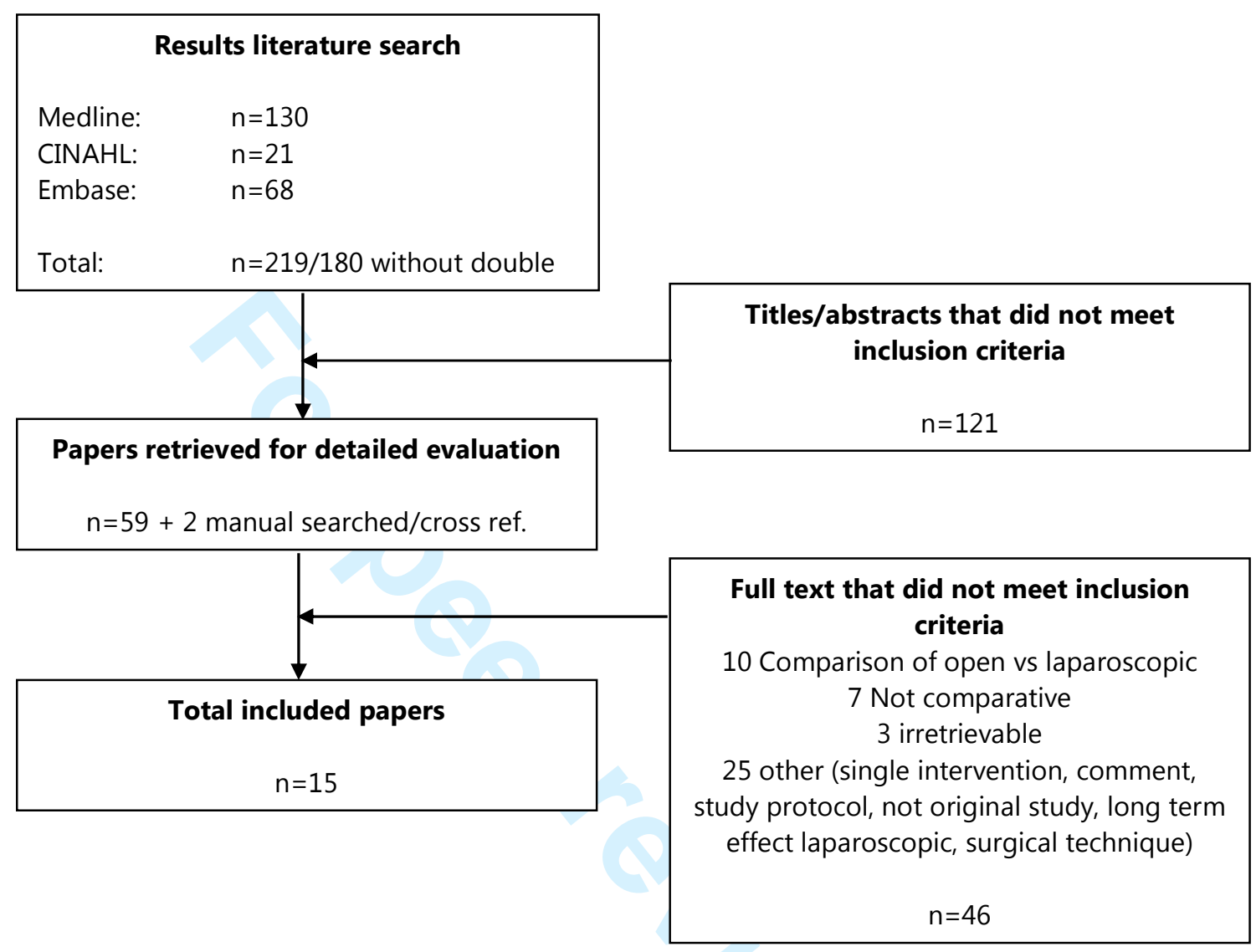


Annex 1. Characteristics of included studies

\begin{tabular}{|c|c|c|c|c|c|c|c|}
\hline Author, year & Study type & $\begin{array}{l}\text { Level of } \\
\text { evidence }\end{array}$ & $\begin{array}{l}\text { Population, Intervention } \\
\text { (control) }\end{array}$ & Main outcome measures & \multicolumn{2}{|l|}{ Results } & $\begin{array}{l}\mathbf{N r} \\
\mathbf{K I}\end{array}$ \\
\hline $\begin{array}{l}\text { Alcantara- } \\
\text { Moral, } 2014\end{array}$ & $\begin{array}{l}\text { Observational, } \\
\text { cross- } \\
\text { sectional, } \\
\text { multicenter }\end{array}$ & 4 & $\begin{array}{l}\text { Coloncancer } \\
N=190(173)\end{array}$ & $\begin{array}{l}\text { LOS } \\
\text { Morbidity } \\
\text { Readmission rate }\end{array}$ & \multicolumn{2}{|c|}{$\begin{array}{l}5.2 \text { vs } 6.2 d(p<0.05) \\
31.1 \text { vs } 24.3 \%(n s) \\
3 \text { vs } 5 \%(n s)\end{array}$} & 13 \\
\hline $\begin{array}{l}\text { Christensen, } \\
2011\end{array}$ & $\begin{array}{l}\text { Retrospective } \\
\text { observational }\end{array}$ & 4 & $\begin{array}{l}\text { Maligne, benigne, open elective } \\
\text { colorecatal resections } \\
N=131 \text { (39) }\end{array}$ & $\begin{array}{l}\text { LOS } \\
\text { Complication rates } \\
\text { Readmissions }\end{array}$ & \multicolumn{2}{|c|}{$\begin{array}{l}3 \text { vs } 7 d(p<0.0001) \\
\text { No differences } \\
15 \% \text { vs } 16 \%(n s)\end{array}$} & 19 \\
\hline Feo, 2009 & Controlled trial & 3 & $\begin{array}{l}\text { Colorectal resections, elective } \\
\mathrm{N}=50(50)\end{array}$ & $\begin{array}{l}\text { Complication rate } \\
\text { Morbidity } \\
\text { LOS }\end{array}$ & \multicolumn{2}{|c|}{$\begin{array}{l}28 \text { vs } 26 \% \text { (ns) } \\
22 \text { vs } 32 \% \text { (ns) } \\
5 \text { vs } 7 d(p<0.001)\end{array}$} & 9 \\
\hline Gouvas, 2012 & $\begin{array}{l}\text { Multicenter, } \\
\text { comparative, } \\
\text { prospective }\end{array}$ & 3 & $\begin{array}{l}\text { Open en lap. Sphincter } \\
\text { preserving rectal resection } \\
\mathrm{N}=156 \text { in } 4 \text { groups: Open } \\
\text { Fasttrack (36), Lap Fasttrack } \\
\text { (42), Open Usual care (45), Lap } \\
\text { Usual care (33) }\end{array}$ & $\begin{array}{l}\text { Mortality } \\
\text { Major morbidity / complications } \\
\text { Readmission } \\
\text { LOS }\end{array}$ & $\begin{array}{l}\text { Lap: } \\
2.4 \text { vs } 0 \text { (ns) } \\
21.4 \text { vs } 51.5 \\
(p=0.007) \\
\text { ns } \\
4 \text { vs } 8 d \\
(p<0.001)\end{array}$ & $\begin{array}{l}\text { Open: } \\
2.8 \text { vs } 0 \text { (ns) } \\
38.9 \text { vs } 55.6 \\
(p=0.007) \\
\text { ns } \\
7 \text { vs } 8 d \\
(p=0.001)\end{array}$ & 14 \\
\hline $\begin{array}{l}\text { Huibers, } \\
2012\end{array}$ & $\begin{array}{l}\text { Retrospective } \\
\text { comparative }\end{array}$ & 4 & $\begin{array}{l}\text { Laparoscopic TME, Rectal } \\
\text { cancer } \\
\mathrm{N}=43 \text { (33) }\end{array}$ & $\begin{array}{l}\text { Postoperative LOS } \\
\text { Complications } \\
\text { Readmission }(<30 \mathrm{~d}) \\
\text { Mortality }(<30 \mathrm{~d}) \\
\end{array}$ & \multicolumn{2}{|c|}{$\begin{array}{l}7 \text { vs } 10 d(p=0.04) \\
\text { ns } \\
11.6 \text { vs } 18.2 \% \text { (ns) } \\
0 \text { vs } 0\end{array}$} & 20 \\
\hline $\begin{array}{l}\text { Ionescu, } \\
2009\end{array}$ & $\begin{array}{l}\text { Randomised } \\
\text { Controlled } \\
\text { Trial }\end{array}$ & 2 & $\begin{array}{l}\text { Colorectal cancer, open } \\
\mathrm{N}=48 \text { (48) }\end{array}$ & $\begin{array}{l}\text { PONV } \\
\text { LOS in HDU/ICU } \\
\text { LOS } \\
\text { Readmissions } \\
\text { Complications }\end{array}$ & \multicolumn{2}{|c|}{$\begin{array}{l}34.7 \text { vs } 42.8 \%(p=0.538) \\
0.9 \text { vs } 1.8 d(p=0.001) \\
6.4 \text { vs } 9.2 d(p=0.001) \\
\text { No difference } \\
\text { No difference }\end{array}$} & 12 \\
\hline Khoo, 2007 & $\begin{array}{l}\text { Randomised } \\
\text { Controlled } \\
\text { Trial }\end{array}$ & 3 & $\begin{array}{l}\text { Colorectal resections, elective } \\
\mathrm{N}=35 \text { (35) }\end{array}$ & Postop LOS & \multicolumn{2}{|c|}{5 vs $7 d(p<0.001)$} & 13 \\
\hline King, 2006 & Prospective & 3 & Colorectal resections & Postop LOS & \multicolumn{2}{|c|}{5.8 vs $10.7 d(p<0.001)$} & 15 \\
\hline
\end{tabular}




\begin{tabular}{|c|c|c|c|c|c|c|c|}
\hline & comparative & & $\mathrm{N}=60(86)$ & $\begin{array}{l}\text { Readmissions }<30 d \\
\text { Major complications } \\
\text { Mortality }<30 d\end{array}$ & \multicolumn{2}{|c|}{$\begin{array}{l}12 \text { vs } 9 \%(n s) \\
18 \text { vs } 28 \%(n s) \\
3 \text { vs } 7 \%(n s)\end{array}$} & \\
\hline Lloyd, 2010 & $\begin{array}{l}\text { Interrupted } \\
\text { Time Series }\end{array}$ & 4 & $\begin{array}{l}\text { Open or laparoscopic colorectal } \\
\text { resection } \\
\text { Open: } N=25 \text { (22) } \\
\text { Laparoscopic: } N=55(15)\end{array}$ & $\begin{array}{l}\text { Postop LOS } \\
\text { Complication rate }\end{array}$ & $\begin{array}{l}\text { Lap: } \\
6 \text { vs } 9.5 \text { d } \\
(p=0.01) \\
\text { Ns }\end{array}$ & $\begin{array}{l}\text { Open: } \\
7.5 \text { vs } 12 d \\
(p=0.04) \\
\text { ns }\end{array}$ & 8 \\
\hline $\begin{array}{l}\text { Moronczyk, } \\
2011\end{array}$ & $\begin{array}{l}\text { Prospective } \\
\text { comparative }\end{array}$ & 4 & $\begin{array}{l}\text { Colon resection } \\
\mathrm{N}=15 \text { (18) }\end{array}$ & $\begin{array}{l}\text { Complication rate } \\
\text { Mortality } \\
\text { Reoperation rate } \\
\text { Re-hospitalization } \\
\text { LOS }\end{array}$ & \multicolumn{2}{|c|}{$\begin{array}{l}40 \text { vs } 22.2 \%(n s) \\
6.7 \text { vs } 22.2 \%(n s) \\
0 \text { vs } 11.1 \% \\
0 \text { vs } 0 \\
8 \text { vs } 10.5 d(p<0.05)\end{array}$} & 12 \\
\hline Polle, 2007 & $\begin{array}{l}\text { Retrospectively } \\
\text { controlled } \\
\text { comparative }\end{array}$ & 4 & $\begin{array}{l}\text { Elective colorectal resection } \\
\mathrm{N}=55(52)\end{array}$ & $\begin{array}{l}\text { Complication rate } \\
\text { Reoperation rate } \\
\text { LOS } \\
\text { Readmission }<30 d \\
\text { Mortality }<30 d\end{array}$ & \multicolumn{2}{|c|}{$\begin{array}{l}27.3 \text { vs } 30.8 \% \text { (ns) } \\
12.7 \text { vs } 9.6 \% \text { (ns) } \\
4 \text { vs } 6 d(p=0.002) \\
10.9 \text { vs } 5.8 \%(n s) \\
0 \text { vs } 0\end{array}$} & 19 \\
\hline Ren, 2012 & $\begin{array}{l}\text { Randomised } \\
\text { Controlled } \\
\text { Trial }\end{array}$ & 2 & $\begin{array}{l}\text { Elective colorectal resection } \\
\mathrm{N}=299 \text { (298) }\end{array}$ & $\begin{array}{l}\text { Postop LOS } \\
\text { Complications }\end{array}$ & \multicolumn{2}{|c|}{$\begin{array}{l}5.7 \text { vs } 6.6 \mathrm{~d}(\mathrm{p}<0.001) \\
\text { Ns }\end{array}$} & 16 \\
\hline $\begin{array}{l}\text { Schwarzbach, } \\
2011\end{array}$ & $\begin{array}{l}\text { Interrupted } \\
\text { Time Series }\end{array}$ & 4 & $\begin{array}{l}\text { Colon resections } \\
\mathrm{N}=78(133)\end{array}$ & $\begin{array}{l}\text { LOS } \\
\text { Morbidity } \\
\text { Mortality } \\
\text { Readmission rate }\end{array}$ & \multicolumn{2}{|c|}{$\begin{array}{l}9 \text { vs } 9 d(p=0.84) \\
28.2 \text { vs } 32.3 \%(p=0.53) \\
1.3 \text { vs } 2.2 \%(p=1) \\
2.6 \text { vs } 3.8(p=1)\end{array}$} & 14 \\
\hline Wang, 2012 & $\begin{array}{l}\text { Randomised } \\
\text { Controlled } \\
\text { Trial }\end{array}$ & 2 & $\begin{array}{l}\text { Lap. Colon resections } \\
\mathrm{N}=49(50)\end{array}$ & $\begin{array}{l}\text { Postop LOS } \\
\text { Complication rate }\end{array}$ & \multicolumn{2}{|c|}{$\begin{array}{l}4 \text { vs } 5 d(p<0.01) \\
12 \text { vs } 20 \% \text { (ns) }\end{array}$} & 13 \\
\hline Wang, 2011 & $\begin{array}{l}\text { Randomised } \\
\text { Controlled } \\
\text { Trial }\end{array}$ & 2 & $\begin{array}{l}\text { Colorectal cancer } \\
\mathrm{N}=104(106)\end{array}$ & $\begin{array}{l}\text { Morbidity }<30 \text { days } \\
\text { Postop LOS } \\
\text { Readmission rate }\end{array}$ & \multicolumn{2}{|c|}{$\begin{array}{l}14 \text { vs } 28 \text { patients }(p=0.016) \\
5 \text { vs } 7 d(p<0.01) \\
4 \text { vs } 9 \%(n s)\end{array}$} & 19 \\
\hline
\end{tabular}

$\mathrm{D}=$ days; $\mathrm{KI}=$ number of key interventions used in study;ns=not significant 


\section{Annex 2. Components Care Pathway for surgical patients with colorectal cancer}

\begin{tabular}{l} 
Day $0=$ day of surgery, day $1=1^{\text {st }}$ postoperative day, et cetera. Blue $=$ add on to ERAS protocol \\
\hline \multicolumn{1}{|c|}{ General } \\
\hline $\begin{array}{l}\text { Dedicated ward } \\
\text { Patients admitted on } 1 \text { ward (Christensen; Khoo) }\end{array}$ \\
\hline Dedicated team \\
Fast track team: surgeons, nurses, anesthetists (Christensen) and pain management, physical therapy, social work (Feo) \\
\hline $\begin{array}{l}\text { OR scheduling } \\
\text { Patients first on operating program and scheduled for surgery on Tuesdays or Wednesdays to avoid discharge on weekends (Christensen) }\end{array}$ \\
\hline
\end{tabular}

Preadmission counseling $\quad$ Pre-operative care

ERAS: patients should routinely receive dedicated preoperative counseling (Gustafsson)

Information on the consecutive steps of postoperative care (Ionescu; Moronczyk; Wang (2011)) and expected length of stay (Christensen); Pre-operative assessment with written information (King); Written and oral information on Fast Track, informed consent (Huibers; Polle); Guided tour on surgical ward (Polle); Written and oral information, explanation epidural pump (Gouvas)

\section{Fluid and carbohydrate loading}

ERAS: Preoperative oral carbohydrate treatment ( $400 \mathrm{ml}$ of $12.5 \%$ drink of mainly maltodextrins) should be used routinely (Gustafsson)

Liquid protein/calorie supplement from admission, 3 drinks (Khoo; King); Last carbohydrate loaded drink $2 \mathrm{~h}$ before surgery (Polle); $400 \mathrm{ml}$ nutritional supplements before midnight or $6 \mathrm{~h}$ before surgery, $200 \mathrm{ml} 2 \mathrm{~h}$ before surgery (Ren); $100 \mathrm{~g}$ of glucose in $1000 \mathrm{ml}$ of water (glucose injection $10 \%)$ orally administered at $10 \mathrm{pm}$ on the evening before surgery, a further $50 \mathrm{~g}$ of carbohydrate in $500 \mathrm{ml}$ of water given $3-4 \mathrm{~h}$ before surgery (Wang (2012)); Oral nutrition with high-calorie carbohydrate drinks until $2 \mathrm{~h}$ prior to surgery (Gouvas); 4 packages of carbohydrate drinks on day -1 (Wang (2011)); 2 packages of carbohydrate drinks $2 \mathrm{~h}$ before surgery (Huibers; Wang (2011)); Carbohydrate fluids load 3h before surgery (Alcantara-Moral; Ionescu)

\section{No prolonged fasting}

ERAS: Patients should be screened for nutritional status and, if deemed to be at risk of under-nutrition, given active nutritional support. Clear fluids should be allowed up to $2 \mathrm{~h}$ and solids up to $6 \mathrm{~h}$ prior to induction of anesthesia (Gustafsson)

Fluids up to $3 \mathrm{~h}$ before surgery (Khoo); Last meal $6 \mathrm{~h}$ before surgery (Polle; Wang (2011)); Clear fluids until $2 \mathrm{~h}$ before initiation of anesthesia and $6 \mathrm{~h}$ for solid food (Wang (2012)); Oral nutrition with high-calorie carbohydrate drinks until $2 \mathrm{~h}$ prior to surgery (Gouvas); Normal diet until midnight, fluid intake until $2 \mathrm{~h}$ before surgery (Huibers) 


\section{No / selective bowel preparation}

ERAS: Mechanic Bowel Preparation should not be used routinely in colonic surgery (Gustafsson)

No bowel preparation (Alcantara-Moral; Christensen; Ionescu; Ren; Wang (2012); Wang (2011)); No mechanical preoperative bowel preparation (only a small enema allowed) (Moronczyk); Two enemas the evening before surgery (Huibers); Only in the cases of planned intraoperative colonoscopy (Schwarzbach)

\section{Antibiotic prophylaxis}

ERAS: Routine prophylaxis with intravenous antibiotics should be given 30-60 min before initiating colorectal surgery. Additional doses should be given during prolonged procedures according to the half-life of the drug used (Gustafsson)

Cefalozine $(1000 \mathrm{mg})$ and metronidazole $(500 \mathrm{mg})$ IV $30 \mathrm{~m}$ before first incision, repeated after $3.5 \mathrm{~h}$ (Huibers)

\section{Thromboprophylaxis}

ERAS: Patients should wear well-fitting compression stockings, have intermittent pneumatic compression, and receive pharmacological prophylaxis with LMWH. Extended prophylaxis for 28 days should be given to patients with colorectal cancer (Gustafsson)

$0.3 \mathrm{ml}$ fraxiparine from day -1 until discharge (Huibers)

\section{No premedication}

ERAS: Patients should not routinely receive long- or short-acting sedative medication before surgery because it delays immediate postoperative recovery. If necessary, short-acting intravenous drugs can be titrated carefully by the anesthetist to facilitate the safe administration of epidural or spinal analgesia because these do not significantly affect recovery (Gustafsson)

No premedication (Alcantara-Moral; Christensen; Polle; Wang (2011)); Lorazepam 1mg evening before surgery if necessary (Polle); Haloperidol (1.5 mg) intraoperatively (Huibers)

\begin{tabular}{|l|}
\hline \multicolumn{1}{|c|}{ Intra-operative care } \\
\hline Pre-emptive analgesia \\
Epidural pain relief by $0.5 \%$ ropivacaine Preoperatively (Christensen); $4 \times 1000 \mathrm{mg}$ paracetamol from day -1 until discharge (Huibers) \\
\hline Short acting anesthetic agents \\
ERAS: A standard anesthetic protocol allowing rapid awakening should be given (Gustafsson) \\
Propofol or remifentanil (Christensen); Propofol, $1,5-2,5 \mathrm{mg} / \mathrm{kg}$ or $2-4 \mathrm{mg} / \mathrm{kg}$ thiopental or fentanyl $2-3 \mu \mathrm{g} / \mathrm{kg}$ and vecuronium $0.1 \pm 0.02 \mathrm{mg} / \mathrm{Kg}(\mathrm{Feo}) ;$ \\
Propofol (King); Remifentanil $1 \mu \mathrm{g} / \mathrm{kg} / \mathrm{min}$, Propofol $2-4 \mathrm{mg} / \mathrm{kg} / \mathrm{h}$, Cisatracium $0.15 \mathrm{mg} / \mathrm{kg}$ (Wang (2012); Wang (2011)) \\
\hline Midthoracic epidural anesthesia / analgesia \\
ERAS: Mid-thoracic epidural blocks using local anesthetics and low-dose opioids should be considered for open surgery. In laparoscopic surgery, spinal analgesia \\
or morphine PCA is an alternative to epidural anesthesia. If intravenous opioids are to be used the dose should be titrated to minimize the risk of unwanted \\
effects (Gustafsson) \\
Epidural catheter placed between T6 and T9 thoracic vertebrae for right-sided colonic resections, and between T8 and T11 thoracic vertebrae for left-sided \\
resections, by $0.2 \%$ ropivacaine containing $50 \mu \mathrm{g}$ morphine per $\mathrm{ml}$ (Christensen); Between T10 and T12 (Feo; Ionescu); Between T8-T9, bupivicaine $0.5 \%<=$ \\
$10 \mathrm{ml}$, diamorphine $2.5 \mathrm{mg}$ in bupivicaine $0.25 \%$ at wound closure (King); Placement of thoracic epidural catheter (T6-T10, depending on the surgical
\end{tabular}


resection); test-dose (bupivacaine $0.25 \%$ with adrenaline 1:200,000), top-up dose (bupivacaine $0.25 \%( \pm 10 \mathrm{ml})$ with sufentanil $25 \mu \mathrm{g}$, (Polle); Continuous epidural anesthesia combined with general endotracheal anesthesia (Ren); Placed between T6 and T12 (Wang (2012)); Placed between T10 and T12 (Wang (2011)) Test: lidocaine $2 \% 3 \mathrm{ml}$ with epinephrine, bupivacaine 0.5\% (6+6)ml (Wang (2012); Wang (2011)); Placement of epidural catheter unless contraindicated (Alcantara-Moral; Gouvas); Between T9 and T11, levobupivacaine and sufentanil (15); Epidural catheter placement (Schwarzbach)

\section{No drains}

ERAS: Routine drainage is discouraged because it is an unsupported intervention that probably impairs mobilization (Gustafsson)

No drains (Alcantara-Moral; King; Moronczyk; Polle; Wang (2012); Wang (2011)); According to circumstances (Ren)

\section{Avoidance of salt and water overload}

ERAS: Balanced crystalloids should be preferred to $0.9 \%$ saline. In open surgery, patients should receive intraoperative fluids (colloids and crystalloids) guided by flow measurements to optimize cardiac output. Flow measurement should also be considered if: the patient is at high risk with comorbidities; if blood loss is $>7 \mathrm{ml} / \mathrm{kg}$; or in prolonged procedures. Vasopressors should be considered for intra- and postoperative management of epidural-induced hypotension provided the patient is normovolaemic (Gustafsson)

Intraoperative fluids restricted to $1500 \mathrm{ml}$ unless bleeding in excess of $500 \mathrm{ml}$ (Khoo); $2000 \mathrm{ml}$ crystalloid intraoperatively (King); Restricted per-operative fluid infusion regime (Ringers lactate $20 \mathrm{ml} \mathrm{k} \mathrm{k}^{-1}$ in the $1^{\text {st }} \mathrm{h}$ followed by RL $6 \mathrm{ml} \mathrm{k} \mathrm{kg}^{-1} \times \mathrm{h} \mathrm{h}^{-1}$ ) (Polle); Restrictive protocol (4ml/ $\mathrm{kg} / \mathrm{h}$ ) (Ren); Fluid restriction $10 \mathrm{ml} / \mathrm{kg} / \mathrm{h}$; Limited intravenous administration of colloids (Gouvas); Restrictive fluid therapy (Alcantara-Moral); Goal of perioperative fluid management: achieve normovolemia (Schwarzbach)

\section{Maintenance of normothermia}

ERAS: Intraoperative maintenance of normothermia with a suitable warming device and warmed intravenous fluids should be used routinely to keep body temperature $>36^{\circ} \mathrm{C}$. Temperature monitoring is essential to titrate warming devices and to avoid hyperpyrexia (Gustafsson)

Forced body heating (Bair hugger system/warmer coat and warmed IV fluids) (Polle; Ren); Active warming of patient (Alcantara-Moral; Gouvas); Using warm blankets (Huibers)

\section{Incision}

Right-sided horizontal incision was used for right colectomy and transverse resection, and a curved incision in the left iliac fossa was used for left hemicolectomy and sigmoid resection (Christensen); Transverse / curved incision for open surgery (King); Minimal invasive incisions (Polle); Minimal-access surgery or transverse curved incision used included right-sided hemicolectomy through a right horizontal incision above the umbilicus, sigmoid resection through a curved incision in the left iliac fossa (Wang (2011))

\section{Laparoscopic technique}

Based on clinical assessment of the most appropriate method (Lloyd); Laparoscopic in all patients (Huibers; Wang (2012)); Low anterior rectal resection through a mini-laparotomy in the subumbilicus which was extended toward the curvature if necessary (Wang (2012))

\section{Wound infiltration}

Infiltration of surgical wounds with bupivacaine (Moronczyk; Polle; Wang (2011))

\section{Standard ASA monitors}

EKG, blood pressure, pulse oximetry (Feo) 


\section{Mid-thoracic epidural anesthesia / analgesia}

Post-operative care

ERAS: Thoracic Epidural Analgesia (TEA) using low-dose local anesthetic and opioids should be used in open surgery. For breakthrough pain, titration to minimize the dose of opioids may be used. In laparoscopic surgery, an alternative to TEA is a carefully administered spinal analgesia with a low-dose, longacting opioid (Gustafsson)

Epidural catheter placed between T6 and T9 thoracic vertebrae for right-sided colonic resections, and between T8 and T11thoracic vertebrae for left-sided resections, by $0.2 \%$ ropivacaine containing $50 \mu \mathrm{g}$ morphine per milliliter. Second postoperative day: removal of epidural catheter (Christensen)

Between T10 and T12, 30 minutes before end of surgery bolus of ropivacaine $0.75 \% 10 \mathrm{ml}$, infusion of ropivacaine $2 \% 5-10 \mathrm{ml} / \mathrm{h}$, for $48 \mathrm{hrs}$ (Feo); Thoracic epidural, bupivacaine $0.167 \%$ and diamorphine, for $48 \mathrm{hrs}$ (Khoo); Continuous epidural analgesia ( 2 days) $5 \mathrm{mg}$ diamorphine in $60 \mathrm{ml}$ bupivicaine $0.125 \%$ at

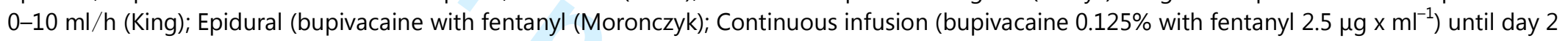

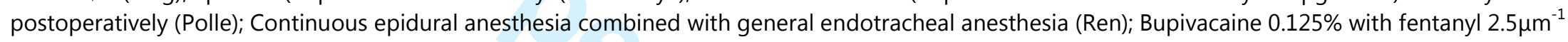
(Wang (2012); Wang (2011)); Day 1 epidural analgesia with continuous infusion of local anesthetics (epidural-PCA) (Gouvas); Remove epidural catheter if pain score (VAS) < 4 (Huibers); Bupivacaine $0.125 \%+$ fentanyl $2 \mu \mathrm{g} / \mathrm{ml}$ via epidural catheter (Ionescu); Epidural catheter placement (Schwarzbach)

\section{No nasogastric tubes}

ERAS: Postoperative nasogastric tubes should not be used routinely. Nasogastric tubes inserted during surgery should be removed before reversal of anesthesia (Gustafsson)

No NG tube (Alcantara-Moral; Feo; Huibers; King; Moronczyk; Ren); Removal in recovery room (Khoo); remove before leaving Operating Theatre (Lloyd; Schwarzbach); Removal of NG tube before extubation (Gouvas; Polle); no NG tube unless severe PONV (Ionescu; Wang (2011))

\section{Prevention of nausea and vomiting}

ERAS: A multimodal approach to PONV prophylaxis should be adopted in all patients with $\geq 2$ risk factors undergoing major colorectal surgery. If PONV is present, treatment should be given using a multimodal approach (Gustafsson)

Treatment of nausea (Christensen); regular Domperidone, magnesium hydroxide 8\% (Khoo); Ondansetron (4 mg) (King; Polle; Wang (2012); Wang (2011)); Combination of dexamethasone and tropisetron (Ren); Dexamethasone ( $5 \mathrm{mg}$ ) and ondansetrone (4mg) preoperatively (Huibers); Metoclopramide IV $10 \mathrm{mg}$ every 8h, ondansetrone only for severe PONV (Ionescu); Using prokinetics (Alcantara-Moral)

\section{Avoidance of salt and water overload}

ERAS: The enteral route for fluid postoperatively should be used as early as possible, and intravenous fluids should be discontinued as soon as is practicable (Gustafsson)

Free oral fluids immediately after the operation, discontinue IV fluids when patient is able to tolerate $200 \mathrm{ml}$ of water over 30 minutes (Khoo); Day 0: 1 liter oral intake, 2 protein drinks, day 1: 4 protein drinks (Christensen); 1 high protein/high calorie drink on day 0, 3 high protein/high calorie drinks per day thereafter, Free fluids from day 0 (King; Lloyd); Oral fluid from day 0, limiting IV fluid in favor of oral (Moronczyk); First oral drinks at $2 \mathrm{~h}$ post-surgery + IV infusion of RL 1.5 liters $x$ day $^{-1}$, day 1 oral intake $>2$ ( (including 4 units CHL drinks), stop IV fluid administration (leave cannula) (Polle; Wang (2011)); Restrictive protocol, $1500 \mathrm{ml} /$ day, $500 \mathrm{ml}$ water starting at $6 \mathrm{~h}$ after surgery on day 0 and $500 \mathrm{ml}$ nutritional supplements and $1000 \mathrm{ml}$ water daily postoperatively (Ren); Day 0, oral fluid intake directly encouraged, IV fluid restricted to 1 liter per 24h (Huibers); High-calorie drinks a few hours after surgery 
(Gouvas); Goal of perioperative fluid management: achieve normovolemia, remove venous canula as soon as patient is able to drink (Schwarzbach)

\section{Early removal of catheter}

ERAS: Routine transurethral bladder drainage for 1-2 days is recommended. The bladder catheter can be removed regardless of the usage or duration of

Thoracic Epidural Analgesia (Gustafsson)

Day 1 (colon), day 3 (rectum) (Christensen; Feo; Khoo); Day 1 (laparoscopic), day 2 (open) (Lloyd); Early removal (Moronczyk); Suprapubic urine catheter,

close and remove when residue $<50 \mathrm{ml}$ (Polle); Use for the duration of thoracic epidural analgesia and early removal (Ren); Usually within $24 \mathrm{~h}$ (Wang (2012);

Ionescu; Wang (2011)); Removal if urine output $>40 \mathrm{ml} / \mathrm{h}$ (Gouvas); Removal on day 2 (Huibers); Directly after operation (Schwarzbach)

\section{Early oral nutrition}

ERAS: Patients should be encouraged to take normal food as soon as possible after surgery. Oral nutritional supplements can be used to supplement total intake (Gustafsson)

From day 2: normal diet (Christensen); Liquid diet day 1, soft diet day 2 and regular diet as tolerated (Feo); Normal diet allowed immediately after surgery (Khoo); Normal diet offered and encouraged from day 1 (King); Day 1 light diet, day 2 regular diet (Lloyd); Introduction of diet on day 1 (Moronczyk); First semi-solid food intake in the evening, from day 1 offer solid food (Polle); Clear liquid diet after the first postoperative flatus (Ren); Day 1 solid diet (Gouvas); Day 0 liquid diet in the evening, day 1 restart normal diet at noon (Huibers); Day 0 fluids if tolerated, day 1 semi-solid food, day 2 solid food, regular diet (Ionescu); Day 1 semi-solid food, day 2 normal diet (Wang (2012)); Oral diet within $12 \mathrm{~h}$ (Alcantara-Moral); Yoghurt on the evening day 0 and normal diet from day 1 (Schwarzbach)

\section{Non-opioid oral analgesia / NSAIDs}

ERAS: In connection with TEA withdrawal, NSAIDs and Paracetamol should be used (Gustafsson)

Paracetamol or NSAIDs, nicomorphine as rescue medication (Christensen); Paracetamol (1000mg) and ibuprofen (400mg) 4xd (Khoo); Paracetamol 1g 4 hourly from day 1 , Ibuprofen $400 \mathrm{mg} 8$ hourly $+200 \mathrm{mg}$ PRN (max 1.2g/d) once epidural stopped, morphine as rescue medication (King); From day 1 tramadol and NSAID (Lloyd); Analgesia complemented with parenteral, and then oral NSAIDs, paracetamol or tramadol, opiod as needed (Moronczyk); paracetamol 4x $1 \mathrm{~g} \mathrm{x} \mathrm{d}^{-1}$, from day 2 add NSAID (Polle); Patient-controlled analgesia and oral NSAIDs (Ren); Analgesia with NSAIDs or paracetamol intramuscularly (Gouvas); diclofenac 50mg 3xd from day 2 (Huibers; Wang (2011)); Ketorolac IV 60mg/8h the first 48h and orally after, and paracetamol $1 \mathrm{~g} / 8 \mathrm{~h}$ orally (or intravenously if PONV) (Ionescu); No opiods (Alcantara-Moral); Additional standardized oral analgesic scheme: ibuprofen 400mg 2x day, metamizol $1 \mathrm{~g} 3 x$ day and, only if required, oxycodone/naloxone 10/5mg 2x day (Schwarzbach)

\section{Early mobilization}

ERAS: Prolonged immobilization, increases the risk of pneumonia, insulin resistance, and muscle weakness. Patients should therefore be mobilized (Gustafsson) Day 0: out of bed for $>2 \mathrm{~h}$, day 1 : out of bed for $>8 \mathrm{~h}$ (Christensen, King); Resume physical activities day 1 (Feo; Khoo); 4 x 60m walks from day 1 (King); Mobilize bed-chair evening of surgery, walk $100 \mathrm{~m}$ by the end of day 1 , more than $100 \mathrm{~m}$ the following day (Lloyd); Attempt at bedside rehabilitation at day 0 , rehabilitation from day 1 (Moronczyk); Mobilization in the evening ( $>2 \mathrm{~h}$ out of bed); day 1 expand mobilization ( $>6 \mathrm{~h}$ out of bed), day 2 expand mobilization (>8h out of bed) (Polle; Wang (2011)); Out of bed for $2 \mathrm{~h}$ on day 1 and 4-6h each day thereafter (Ren); Encourage patients to ambulate early (Wang (2012)); Mandatory $1 \mathrm{~h}$ mobilization out of bed on day 0, 4h mobilization out of bed on day 1, fully mobilized on day 2 (Gouvas); Day $12-3 \mathrm{~h}$ of mobilization, day 2 stimulate to fully mobilize (Huibers); Day 0 mobilized in bed (turning, sitting in bed), day 1 mobilized out of bed (Ionescu); Mobilization 
at 24h (Alcantara-Moral); Ambulation scheduled to start on the evening of day 0 (Schwarzbach)

\section{Stimulation of gut motility}

ERAS: Chewing gum can be recommended, whereas oral administration of magnesium and alvimopan (when using opioid based analgesia) can be included

(Gustafsson)

Prokinetics (Alcantara-Moral; Christensen); Infusion of raw rhubarb $10 \mathrm{~g} 5 \mathrm{x}$ day after surgery, injection of neostigmine $0.5 \mathrm{mg}$ at each Zusanli acupoint daily

after surgery (Ren); Start magnesium oxide on day 1 (Huibers); Postoperative bowel activity was stimulated by oral laxatives (magnesium oxide) and enemata

if needed (Schwarzbach)

\section{Audit of compliance and outcomes}

ERAS: A systematic audit is essential to determine clinical outcome and measure compliance to establish successful implementation of the care protocol. The system should also report patient experience and functional recovery, but validated tools are required for this aspect (Gustafsson)

Evaluating discharge criteria; discharge if fulfilled (Feo; Gouvas; Huibers; Ionescu; Khoo; Lloyd; Moronczyk; Polle; Ren; Schwarzbach; Wang (2012); Wang

\section{Routine monitoring at Medium Care Unit}

Routine postoperative monitoring of patients at the intermediate care unit was done when deemed necessary by the surgeon and/or anesthesiologist (Schwarzbach)

\section{Respiratory training}

Every patient was instructed to perform respiratory training with an incentive spirometer (Schwarzbach)

\section{Body weight}

At discharge (Christensen) 